\title{
Unexpected enlargement of cardiac rhabdomyoma after spontaneous regression has begun in a newborn: A case report
}

\section{Bir yenidoğanda kendiliğinden gerilemeye başladıktan sonra beklenmedik şekilde büyüyen kardiyak rabdomiyom: Olgu sunumu}

\author{
İrfan Oğuz Şahin ${ }^{1}$, Meriç Kaymak Cihan², Fatih Bolat ${ }^{3}$, Hazım Alper Gürsu', Mehmet Atalar ${ }^{5}$, \\ Esra Muslu Sayar ${ }^{6}$ \\ ${ }^{1}$ Çocuk Kardiyolojisi Bilim Dalı, Çocuk Sağı̆̆̆ ve Hastalıkları Ana Bilim Dalı, Cumhuriyet Üniversitesi Tıp \\ Fakültesi, Sivas, Türkiye \\ ${ }^{2}$ Çocuk Hematoloji ve Onkolojisi Bilim Dalı, Çocuk Sağlı̆̆ ve Hastalıkları Ana Bilim Dalı, Cumhuriyet \\ Üniversitesi Tip Fakültesi, Sivas, Türkiye \\ ${ }^{3}$ Neonatoloji Bilim Dalı, Çocuk Sağlığı ve Hastalıkları Ana Bilim Dalı, Cumhuriyet Üniversitesi Tıp Fakültesi, \\ Sivas, Türkiye \\ ${ }^{4}$ Çocuk kardiyolojisi, Sivas Devlet Hastanesi, Türkiye \\ ${ }^{5}$ Radyoloji Ana Bilim Dalı, Cumhuriyet Üniversitesi Tıp Fakültesi, Sivas, Türkiye \\ ${ }^{6}$ Çocuk Sağlığı ve Hastalıkları Ana Bilim Dalı, Cumhuriyet Üniversitesi Tıp Fakültesi, Sivas, Türkiye
}

Dergiye Ulaşma Tarihi: 31.05.2016 Dergiye Kabul Tarihi: 01.11.2016 Doi: 10.5505/aot.2017.08860

\section{ÖZET}

Kardiyak rabdomiyom (KRM) çocuklarda primer kardiyak tümörlerin en yaygın tipidir. Prognoz genellikle iyidir ve kendiliğinden gerileyip kaybolması neredeyse KRM doğası gereği olması beklenen bir sonuçtur. Bu yazıda doğum öncesi tespit edilen büyük KRM olan bir yenidoğan sunulmuştur. Takipte KRM'in doğuma kadar büyüdüğü ve doğumdan sonra beklendiği üzere kendiliğinden küçüldüğü görülmüştür. Yedinci günde KRM'in tekrar büyüdüğü ve mitral kapak üzerine yerleşik yeni bir KRM'in de eklenmesi ile önemli subaortik darlığa yol açtı̆̆ı görülmüştür. Cerrahi girișim teknik zorluklar nedeniyle planlanmamış ve everolimus başlanmıştır. Olgu yaşamının 12. gününde kaybedilmiştir. Sonuç olarak, tam mekanizma anlaşılmadığı sürece, kendiliğinden gerileme KRM'ler için doğal bir sonuç olarak beklenmemeli ve KRM olan bütün yenidoğanlar kendiliğinden küçülme başlamış olsalar da muhtemel büyüme yönünden dikkatle takip edilmelidirler.

Anahtar Kelimeler: Kardiyak rabdomiyom, Kendiliğinden neoplazi gerilemesi, Yenidoğan

\begin{abstract}
Cardiac rhabdomyoma (CRHM) is the most common type of primary cardiac tumors in children. The prognosis is generally favourable and spontaneous regression is almost accepted as natural history for CRHM. This report presents a newborn with large CRHM that was diagnosed prenatally. In the follow up, CRHM was enlarged until birth and spontaneously regressed after birth as expected. At the 7th day, CRHM was enlarged again and formed moderate subaortic stenosis with addition of a new CRHM located on the mitral valve. Surgical intervention was not planned for technical difficulties and everolimus was started. The patient was exitus at the 12th day of his life. In conclusion, until the exact mechanism is not understood, regression must not be accepted as natural history of CRHM and all of the newborns with CRHM including those that spontaneous regression begun must be followed carefully for possible enlargement.
\end{abstract}

Keywords: Cardiac rhabdomyoma, Spontaneous neoplasm regression, Newborn

\section{Introduction:}

Primary cardiac tumors are rare with an incidence of $0.027-0.8 \%$ in pediatric autopsies and the most common type is cardiac rhabdomyoma (CRHM) (1). CRHMs are highly associated with tuberous sclerosis (TS) (2). Although CRHMs can enlarge in utero and early neonatal period, they are expected to regress spontaneously after birth (2,3). CRHMs 
are generally asymptomatic but may result serious consequences like arrhytmias, obstruction, heart failure and sudden death according to their location (4).

Herein, we present a newborn with CRHM that was first regressed spontaneously and then re-enlarged. According to our knowledge, re-enlargement of CRHMs after regression begun was not reported previously in the literature. Written informed consent was obtained from the patients parents.

\section{Case Report:}

A term male infant was born at 37 weeks' of gestational age with a birth weight of $2.30 \mathrm{~kg}$ $\left(3^{\text {th }}-10^{\text {th }}\right.$ percentiles $)$. The prenatal ultrasound performed since $25^{\text {th }}$ week had shown a large CRHM that was diminishing interventricular septum and occupying the most of the left and right ventricles (Fig. 1A). CRHM slightly increased in size but no evidence of ventricular outflow obstruction was observed at the prenatal follow up period. At birth, echocardiography confirmed the CRHM without hemodynamic consequences (Fig. 1B). Physical examination, family history, transfontanel-transabdominal ultrasounds and mutation analysis were negative for TS. Telecardiography showed massive cardiomegaly (Fig. 2A). There were not clues for respiratory distress or pneumonia. The serial echocardiography studies during the first days showed spontaneous reduction in size of the CRHMs (Fig. 1C). Oxygen saturation was \%8894 but there was severe respiratory acidosis (pH: 7.0-7.1, $\mathrm{pCO}_{2}: \quad 65-70 \mathrm{mmHg}$ ) against adequate mechanic ventilation support. Thorax computerized tomography showed bilateral lung immaturity and serious cardiomegaly that lessens lung capacity (Fig. 2B). At the $7^{\text {th }}$ day of life, CRHM was enlarged to its first size and a new CRHM (7.9x10.6 mm) was visualized on the mitral anterior leaflet (Fig. 1D). These formed a moderate subaortik stenosis (Fig. 1E). Considering the hemodynamic and respiratory consequences of the CRHMs and the technical challenges of cardiac surgery for diminished interventricular septum, pharmacological size reduction was contemplated with a multidisciplinary meeting. After parents approval, enteral everolimus $0.25 \mathrm{mg} 2$ days a week was started on the $7^{\text {th }}$ day of life in the absence of any infections. Electrolytes, complete blood count, blood urea nitrogen, creatinine, hepatic enzymes and triglyceride monitoring has yielded no concerns during treatment. Severe respiratory acidosis was persisted during treatment. The patient was exitus at the $12^{\text {th }}$ day of his life without a chance to see the effect of everolimus.

\section{Discussion:}

Although rare, CRHMs account for up to $80 \%$ of fetal cardiac tumors (5). Approximately $80 \%$ of children with CRHM have clinical or radiologic findings or family history of TS (4). Our case had no features of TS and was one of the cases with isolated CRHM.

The natural history of CRHMs is generally favorable and they regress beyond the $3^{\text {rd }}$ trimester (2); however enlargement $2^{\text {nd }}-3^{\text {rd }}$ trimesters and early neonatal period is frequent (6-8). After birth, it is expected CRHMs to regress partially or completely during the first year of life (5). Complete resolution of the CRHMs occurs at more than $80 \%$ of cases within infancy and early childhood (2). Although the regression mechanism is not yet well understood, it is thought to be associated with decreasing levels of maternal hormones. In a report, CRHM was regressed completely with 3 months of everolimus and then enlarged in 2 weeks after cessation. Rapid regression of the tumor was documented after medication again. Our patient has distinction of showing both spontaneous regression (Fig. 1C) and reenlargement (Fig. 1d) of CRHM in the early neonatal period. An additonal CRHM was observed on the mitral anterior leaflet at the $7^{\text {th }}$ day (Fig. 1D). Actually, we think that it was not a new CRHM and enlarged old CRHM that could not be visualized before. According to our knowledge, our case is the first one that showed spontaneous re-enlargement after spontaneous regression in the literature.

Conservative approaches remain as standard treatment for cardiac CRHMs in the absence of severe hemodynamic sequelae owing to the natural process of tumor regression over time (5). Although most CRHMs are asymptomatic; heart failure, arrhythmias, intracardiac blood flow obstruction and respiratory system problems related to CRHM are rarely reported depending on CRHM's 
localization (9). Surgical treatment is suggested for these consequences in the absence of technical problems (10).

We planned to observe the patient in intensive care unit and the first 3 days was satisfactory. At the $7^{\text {th }}$ day, moderate subaortic stenosis was formed with the enlargement of opposite CRHMs located at the left ventricle outflow tract (Fig. 1E). Additionally, there was a severe and persistent respiratory acidosis thought to be associated with serious cardiomegaly that lessens lung capacity. Curative surgical treatment was not possible due to diminished and extremely involved interventricular septum. Medical alternatives were discussed in multidisciplinary meeting of neonatology, pediatric cardiology and pediatric hematology specialists.

Although they are not approved by Food and Drug Administration, mammalian target of rapamycin (mTOR) inhibitors are currently under investigation as a treatment option for CRHMs especially for those with technical difficulties for surgery (11). Everolimus appears to be a reasonable therapeutic alternative to surgery in symptomatic infants in whom spontaneous regression cannot be awaited (5) and succesful results are reported with everolimus $(3,5,11,12)$. Adverse effects of everolimus include myelosuppression, peripheral edema, increased
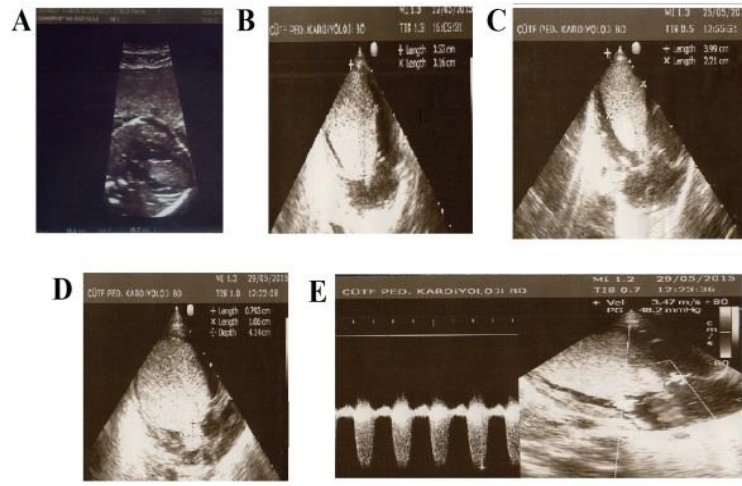

Figure 1: Echocardiographic images of the patient. (A) Two dimensional view at the 25 th weeks of gestation, (B) at the 1st day after birth, (C) at the 3rd day after birth (D) at the 7th day after birth and (E) continious wave Doppler showing subaortic moderate stenosis. creatinine level, diarrhea, nausea, urinary tract infections, hyperlipidemia, hypertriglyceridemia, mouth ulcers, hepatotoxicity, proteinuria, and impaired wound healing (13).

We decided to use everolimus to minimize the CRHMs but the patient was exitus at the $5^{\text {th }}$ day of treatment. It is not possible to mention the efficacy or adverse effect profile of everolimus owing to insufficient treatment period in our case.

\section{Conclusion:}

The natural progression of cardiac rhabdomyomas is to regress after birth. This is thought to be related with decreasing levels of maternal hormones but the exact mechanism is unknown. Our case showed that an unnatural scenerio in which re-enlargement after regression period is possible and must be kept in view. We believe that further studies will clarify the exact mechanism of regression and will provide knowledge to guess which CRHMs would regress and which would not.

\section{Conflict of interest: None}
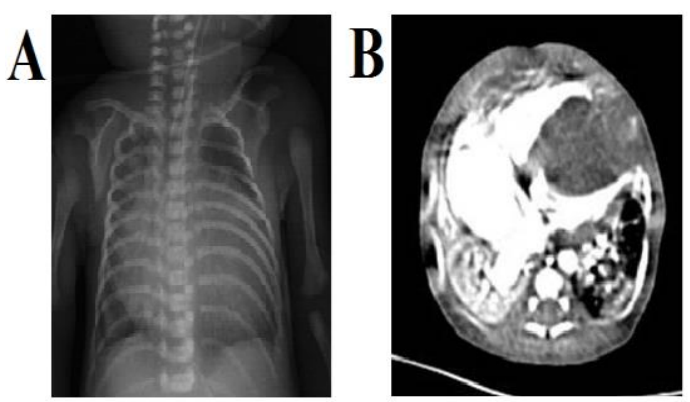

Figure 2: (A) Telecardiography and (B) thorax computerized tomography views of the patient showing serious cardiomegaly and lung immaturity. 


\section{References}

1. Nadas AS, Ellison RC. Cardiac tumors in infancy. Am J Cardiol. 1968;21:363-66

2. Bader RS, Chitayat D, Kelly E, et al. Fetal rhabdomyoma: prenatal diagnosis, clinical outcome and incidence of associated tuberousclerosis complex. J Pediatr. 2003;143:620-4

3. Tiberio D, Franz DN, Phillips JR. Regression of a cardiac rhabdomyoma in a patient receiving everolimus. Pediatrics. 2011;127:1335-7

4. Atalay S, Aypar E, Uçar T, et al. Fetal and neonatal cardiac rhabdomyomas: clinical presentation, outcome and association with tuberous sclerosis complex. Turk J Pediatr. 2010;52:481-7

5. Mlczoch E, Hanslik A, Luckner D, Kitzmüller E, Prayer D, Michel-Behnke I. Prenatal diagnosis of giant cardiac rhabdomyoma in tuberous sclerosis complex: a newtherapeutic option with everolimus. Ultrasound Obstet Gynecol. 2015;45:618-21

6. Tworetzky W, McElhinney DB, Margossian R, et al. Association between cardiac tumors and tuberous sclerosis in the fetus and neonate. Am J Cardiol. 2003;92:487-9

7. Watanabe T, Hojo Y, Kozaki T, Nagashima M, Ando M. Hypoplastic left heart syndrome with rhabdomyoma of the left ventricle. Pediatr Cardiol. 1991;12:121-2

8. Nir A, Ekstein S, Nadjari M, Raas-Rothschild A, Rein AJ. Rhabdomyoma in the fetus: illustration of tumor growth during the second half of gestation. Pediatr Cardiol. 2001;22: 515-8

9. Goyer I, Dahdah N, Major P. Use of mTOR inhibitor everolimus in three neonates for treatment of tumors associated with tuberous sclerosis complex. Pediatr Neurol. 2015;52:4503

10. Castilla Cabanes E, Lacambra Blasco I. Multiple cardiac rhabdomyomas, wolff-Parkinson-white syndrome, and tuberous sclerosis: aninfrequent combination. Case Rep Pediatr. 2014; 973040

11. Doğan V, Yeşil Ş, Kayalı Ş, et al. Regression of symptomatic multiple cardiac rhabdomyomas associated with tuberous sclerosiscomplex in a newborn receiving everolimus. J Trop Pediatr. 2015;61:74-7

12. Demir HA, Ekici F, Yazal Erdem A, Emir S, Tunç B. Everolimus: a challenging drug in the treatment of multifocal inoperable cardiac rhabdomyoma. Pediatrics. 2012;130:243-7

13. Gurk-Turner C, Manitpisitkul W, Cooper M. A comprehensive review of everolimus clinic reports: a new mammalian target of rapamycin inhibitor. Transplantation. 2012;94:659-68 